\title{
PURIFICATION AND CHARACTERIZATION OF MOUSE GLUCOSE 6-PHOSPHATE DEHYDROGENASE
}

\author{
Chi-Yu LEE, James H. YUAN*, David MOSER \& James M. KRAMER $\dagger$ \\ Laboratory of Environmental Mutagenesis, National Institute of Environmental Health Sciences, \\ Research Triangle Park, North Carolina, 27709
}

(Received September 15, 1978)

\section{Summary}

Glucose-6-phosphate dehydrogenase was purified to homogeneity from testes and kidneys of the inbred strain of mice (DBA/2J) by a simple two-step affinity column procedure. This involved the sequential application of 8-(6aminohexyl)-amino-AMP- and -2', 5'-ADPSepharose columns and biospecific elution with $\mathrm{NADP}^{+}$in both steps. The molecular and biochemical properties of the purified enzyme were studied in detail. These include the molecular weight determination, amino acid composition, steady-state kinetics, inactivation by high temperature, urea and iodoacetate, and immunology. The purified enzyme from mouse kidneys or testes was shown to be a tetramer with a molecular weight of 220,000 . The enzyme is highly specific for glucose-6-phosphate, exhibits almost no activity with $\mathrm{NAD}^{+}$as a coenzyme and is little inhibited by AMP or ATP. Michaelis constants for glucose-6phosphate and NADP ${ }^{+}$were determined to be $50 \mu \mathrm{M}$ and $10 \mu \mathrm{M}$ respectively. NADPH is a competitive inhibitor of $\mathrm{NADP}^{+}$and has a $\mathrm{K}_{\mathrm{i}}$ of $18 \mu \mathrm{M}$. Rabbit antisera against glucose-6phosphate dehydrogenase were raised. The antisera also cross-react with the same enzyme from human and guinea pig.

\footnotetext{
* Present address: Department of Chemical Sciences, Old Dominion University, Norfolk, Virginia 23508.

† Department of Human Genetics, University of Michigan, School of Medicine, Ann Arber, Michigan, 48109
}

\section{Introduction}

In many mammalian species it has been shown that glucose-6-phosphate dehydrogenase (E.C. 1.1.1.49) is expressed by a gene located on the $\mathrm{X}$-chromosome $\mathrm{e}^{1-3}$. Over 80 genetic variants, distinguishable from one another by kinetic characteristics, electrophoretic mobility, thermal stability or substrate specificity, have been identified in humans ${ }^{4}$. About 40 of these variants have been associated with human genetic diseases such as hemolytic anemia. Most of the genetic variants have resulted from mutations causing structural alteration of the enzyme. Presumably some of the variants arise from amino acid substitutions which may cause no observable changes on the surface charges of proteins and hence the electrophoretic mobility. Such variants might be distinguished by using various biochemical assays ${ }^{4}$.

Recently, we have become involved in the detection of mutant enzymes or variants based on alterations in structure and biochemical properties other than surface charges (electrophoretic mobility). The goal of such studies is the development of a rapid, large scale biochemical screening technique for the mutant enzymes of the mutagen-treated animal populations. The mouse has been the most important laboratory animal for studies in mammalian genetics and environmental mutagenesis. Recently, many enzymes from several inbred strains of mice have been purified and characterized biochemically in our laboratory. It is our intention to employ the biochemical information obtained to identify or detect mutant enzymes 
in the mutagen-treated mouse populations. The inclusion of glucose-6-phosphate dehydrogenase in such studies becomes apparent when one considers that glucose-6-phosphate dehydrogenase-deficiency associated anemia is one of the most common human genetic diseases ${ }^{4}$.

Numerous reports are available regarding the purification of glucose-6-phosphate dehydrogenase from tissues of many species by affinity chromatography ${ }^{5-9}$. Many of these purification procedures require the combination of conventional and affinity column steps. The most commonly employed affinity ligands in affinity columns are the $\mathrm{N}^{6}, \mathrm{C}-8$ or ribosyl-substituted $\mathrm{NADP}^{+}$or $-2^{\prime}, 5^{\prime}-\mathrm{ADP}$ derivatives ${ }^{5-9}$. In this communication we present a procedure which employs two affinity columns to obtain homogeneous glucose-6-phosphate dehydrogenase from testes and kidneys of DBA/2J mice. Detailed structural and biochemical characterization of the purified enzymes are also presented.

\section{Experimental Procedures}

\section{Materials}

The following enzymes and chemicals were obtained from Sigma Chemical Company: bovine serum albumin, rabbit muscle pyruvate kinase, chicken heart lactate dehydrogenase, rabbit muscle malic dehydrogenase, rabbit muscle enolase, rabbit muscle $\alpha$-glycerolphosphate dehydrogenase, AMP, ADP, ATP, $\alpha$-thioglycerol, glucose-6-phosphate, NADP ${ }^{+}$, $\mathrm{NADPH}, \mathrm{NAD}^{+}$and iodoacetate. Acrylamide and 1,6-diamino hexane were obtained from Eastman Chemical Company. The coenzyme analogs; nicotinamide hypoxanthine dinucleotide phosphate $\left(\mathrm{NHDP}^{+}\right)$, thionicotinamide adenine dinucleotide (TNADP ${ }^{+}$) and 3 acetylpyridine adenine dinucleotide phosphate (AcPy)ADP ${ }^{+}$, were products of P-L Biochemicals Inc., Wisconsin. Sepharose 4-B, 6-B and Sephadex G-200 were purchased from Pharmacia. Inbred strain of mice (Mus musculus), DBA/2J were obtained from Jackson Laborattory at 8 weeks of age or older.

\section{Methods}

Affinity columns and tissue preparation Affinity columns, 8-(6-aminohexyl)-aminoAMP-Sepharose and 8-(6-aminohexyl)-amino2', 5'-ADP-Sepharose were prepared according to the previously described procedures ${ }^{6,10}$. The ligand densities of the prepared affinity gels were determined to be 1.7 and $0.7 \mu$ mole per $\mathrm{ml}$ of affinity gels respectively. After each use, the affinity gels were regenerated with solutions of $2 \mathrm{M} \mathrm{NaCl}$ and $6 \mathrm{M}$ urea followed by equilibration with the buffer.

For tissue preparation, the mice were sacrificed by cervical dislocation, Testes and kidneys were removed and were frozen immediately at $-70^{\circ}$ for use later in the enzyme purification.

\section{Enzyme assays}

Assays of glucose-6-phosphate dehydrogenase were performed on a model 25 Beckman spectrophotometer with temperature controlled at $25 \pm 1^{\circ}$. Glucose-6-phosphate dehydrogenase activity was routinely measured with $0.5 \mathrm{~mm}$ $\mathrm{NADP}^{+}, 1 \mathrm{~mm}$ glucose-6-phosphate in a total volume of $1.0 \mathrm{ml}$ in $0.1 \mathrm{M}$ tris- $\mathrm{HCl}$ buffer, $\mathrm{pH} 8.0$ and was followed by an increase in absorbance at $340 \mathrm{~nm}$ upon the addition of enzyme. One unit of enzyme activity is defined as the amount of enzyme which catalyzes the reduction of $1 \mu$ mole of $\mathrm{NADP}^{+}$per minute under the described experimental conditions. The purity of the prepared enzyme was routinely analyzed by acrylamide gel electrophoresis with and without sodium dodecylsulfate. (SDS). The protein concentration was determined by the procedure of BöHLEN et $a l^{11}$.

\section{Molecular weight determination}

The molecular weight of the native glucose-6phosphate dehydrogenase was determined by gel filtration with Sephadex G-200 chromatography in $0.1 \mathrm{M}$ sodium phosphate buffer at $\mathrm{pH} 7.0$ containing $0.1 \mathrm{~mm} \mathrm{NADP}{ }^{+}$and $1 \mathrm{~mm}$ $\alpha$-thioglycerol. The column was separately calibrated with a variety of markers of known molecular weight by the methods of Andrews ${ }^{12}$. The molecular weight of the denatured enzyme was determined by SDS gel electrophoresis with $7.5 \%$ gels and $1 \%$ SDS. 


\section{Amino acid composition analysis}

For amino acid analysis, the protein sample was initially dialyzed exhaustively against $0.01 \mathrm{M}$ ammonium hydroxide solution. It was then lyophilized to complete dryness. The protein samples were subjected to 24,48 , and 72 hours of hydrolysis in the presence of $6 \mathrm{~N}$ constant boiling glass-distilled $\mathrm{HCl}$ under vacuum in sealed test tubes. After the hydrolysis the protein samples were lyophilized and dissolved in citrate buffer for amino acid analysis on a Beckman model 121M automatic amino acid analyzer as described by Moore et $\mathrm{al}^{13}$.

\section{Immunology}

A solution of pure glucose-6-phosphate dehydrogenase from testes of $\mathrm{DBA} / 2 \mathrm{~J}$ mice

$(0.25 \mathrm{mg} / \mathrm{ml})$ was used for immunization of rabbits. Various volumes were brought to $1 \mathrm{ml}$ with Dulbecco's $\mathrm{Ca}^{++}-\mathrm{Mg}^{++}$free phosphate buffer solution and homogenized with equal volumes of Freund's adjuvant, complete for the first injection and incomplete thereafter. Injections were subcutaneous. $250 \mu 1$ were given on the first two injection, $200 \mu \mathrm{l}$ on the third and $150 \mu \mathrm{l}$ on the fourth. (The first three injections were at 10 days interval, and then at 20-30 days intervals.) After the fifth injection, smashed acrylamide gel slices with the enzyme from the same source but with a different preparation were alternated with $100 \mu$ l of the remaining solution ${ }^{20}$. The antisera were positive by test with double immuno-diffusion precipitation after the third bleed.

Immunoelectrophoresis was carried out in $1 \%$ agar, $0.02 \mathrm{M}$ barbital $\mathrm{pH} 8.6$ buffered gels. It was run at $4^{\circ}, 40$ volts with $0.04 \mathrm{M}$ barbitol cell buffer, pH 8.6. Glucose-6-phosphate dehydrogenase activity was stained by incubating at $37^{\circ}$ in a staining solution containing $3 \mathrm{~mm}$ glucose-6-phosphate, $0.2 \mathrm{~mm} \mathrm{NADP}{ }^{+}, 0.2 \mathrm{~mm}$ nitroblue tetrazolium, $0.1 \mathrm{~mm}$ phenazine methosulfate, $1 \mathrm{~mm}$ magnesium chloride, $0.1 \mathrm{M}$ tris- $\mathrm{HCl}, \mathrm{pH} 8.6$.

Enzyme inactivation studies were performed on red blood cell hemolysates. A $10 \%$ freezethaw lysate was centrifuged $(1000 \times \mathrm{g}, 15 \mathrm{~min}$.). The supernatant was appropriately diluted with $0.9 \% \mathrm{NaCl}$ to give approximately $0.5 \mathrm{units} / \mathrm{ml}$ of activity. Various amounts of antisera, normal rabbit serum or $0.9 \% \mathrm{NaCl}$ were added to aliquots of the hemolysate, incubated for
$30 \mathrm{~min}$. at $24^{\circ}$, centrifuged $(1000 \times \mathrm{g}, 15 \mathrm{~min})$ and the supernatant assayed at $37^{\circ}$ for enzyme activity.

\section{Results}

Enzyme purification

An identical procedure was employed to purify glucose-6-phosphate dehydrogenase from testes and kidneys of $\mathrm{DBA} / 2 \mathrm{~J}$ mice. The purification of this enzyme from the testis homogenate is described here in detail.

Step 1. Frozen testes from one thousand DBA/2J mice (about $200 \mathrm{~g}$ ) were homogenized in $200 \mathrm{ml}$ of $10 \mathrm{~mm}$ phosphate buffer, $\mathrm{pH} 6.5$ at $4^{\circ}$ with a Virtis homogenizer. The homogenate was centrifuged at $27,000 \times \mathrm{g}$ for $20 \mathrm{~min}$. The supernatant was then passed through an 8-(6-aminohexyl)-amino-AMPSeparose column $(5 \times 12 \mathrm{~cm})$. No leakage of enzyme activity was observed during the loading of the homogenate to the column. At the end of the loading, the column was fully washed with 4 liters of $10 \mathrm{~mm}$ phosphate buffer, $\mathrm{pH} 6.5$. Glucose-6-phosphate dehydrogenase was then eluted biospecifically with $0.5 \mathrm{~mm} \mathrm{NADP}{ }^{+}$included in the washing buffer. Glucose-6phosphate dehydrogenase was eluted in relatively broad fractions (about $200 \mathrm{ml}$ ).

Step 2. The eluted glucose-6-phosphate dehydrogenase was concentrated to $3 \mathrm{ml}$ in an Amicon Diaflo cell with a PM 10 membrane. It was then dialyzed extensively against $10 \mathrm{mM}$ phosphate buffer at $\mathrm{pH} 6.5$ overnight at $4^{\circ}$ to remove the endogeneous $\mathrm{NADP}^{+}$. The dialysate was then passed through a small 8-(6aminohexyl)-amino-2', 5'-ADP-Sepharose column $(1 \times 15 \mathrm{~cm})$ equilibrated with the same buffer. Glucose-6-phosphate dehydrogenase was quantitatively adsorbed on this affinity column. The column was then fully washed with $50 \mathrm{~mm}$ phosphate buffer at $\mathrm{pH} 6.5$. The enzyme was then eluted with a 0 to $1 \mathrm{mM} \mathrm{NADP}{ }^{+}$linear gradient $(100 \mathrm{ml} \times 100 \mathrm{ml})$ in the same buffer. In the peak fractions the enzyme was shown to be homogeneous by polyacrylamide gel electrophoresis in the presence or in the absence of SDS. The specific activity of the purified enzyme was determined to be 158 units/mg protein. This represents a 5000 fold purification from the crude homogenate. Typical results of this purification procedure are summarized in Table I. 
Table I.

Purification of glucose-6-phosphate dehydrogenase from mouse testes ${ }^{a}$

\begin{tabular}{lccccc}
\hline \multicolumn{1}{c}{$\begin{array}{c}\text { Purification } \\
\text { step }\end{array}$} & $\begin{array}{c}\text { Total } \\
\text { protein } \\
(\mathrm{mg})\end{array}$ & $\begin{array}{c}\text { Total } \\
\text { activity } \\
\text { (units) }\end{array}$ & $\begin{array}{c}\text { Specific } \\
\text { activity } \\
\text { (units/mg) }\end{array}$ & $\begin{array}{c}\text { Yield } \\
(\%)\end{array}$ & $\begin{array}{c}\text { Purification } \\
\text { (fold) }\end{array}$ \\
\hline $\begin{array}{l}\text { 1. Crude Homogenate } \\
\text { 2. 8-(6-Aminohexyl)- } \\
\text { amino-AMP-Sepharose }\end{array}$ & 21,600 & 650 & 0.03 & 100 & 1 \\
$\begin{array}{l}\text { 3. 8-(6-Aminohexyl)- } \\
\text { amino-2', 5'-ADP- }\end{array}$ & 29.5 & 290 & 10 & 44.6 & 333 \\
\hline \begin{tabular}{l} 
Sepharose \\
\hline
\end{tabular} & 0.95 & 150 & 158 & 23.1 & 5333 \\
\hline
\end{tabular}

a Two hundred grams of frozen testes from DBA/2J mice were employed for this purification.

\section{Molecular weight determination}

The molecular weight of the native glucose-6phosphate dehydrogenase was determined by Sephadex gel filtration chromatography where rabbit muscle pyruvate kinase (mol. wt. 234,000 ), chicken heart lactate dehydrogenase (mol. wt. 144,000) and rabbit muscle malate dehydrogenase (mol. wt. 68,000) were employed as standards. From the study on a Sepharose 6B chromatography column, the molecular weight of glucose-6-phosphate dehydrogenase from testes was determined to be $220,000 \pm 20,000$. On a Sephadex G-200 chromatography column, it was determined to be $240,000 \pm 20,000$, when the same protein standards were employed. The subunit molecular weight was derermined for the denatured enzyme by SDS polyacrylamide gel electrophoresis using bovine serum albumin (mol. wt. 68,500 ), rabbit muscle enolase (subunit mol. wt. 41,000 ) and rabbit muscle L- $\alpha$ glycerophosphate dehydrogenase (subunit mol. wt. 34,000 ) as standards. From this study, the subunit molecular weight of glucose-6phosphate dehydrogenase was determined to be $55,000 \pm 3,000$.

\section{Amino acid analyses}

The results of the amino acid analyses are presented in Table II. The values and their standard deviations were calculated from two separate analyses of duplicates of 24-, 48- and 72- hour hydrolysates. The values of threonine, serine and methionine were obtained by extrapolation to zero hydrolysis time. For the remaining amino acids, the average values were reported.
Table II

Amino acid composition of mouse glucose-6-phosphate dehydrogenase

\begin{tabular}{lcc}
\hline Amino acid & $\begin{array}{c}\text { Average or } \\
\text { extrapolated value }\end{array}$ & $\begin{array}{c}\text { Nearest } \\
\text { integer }\end{array}$ \\
\hline Lysine & Moles/ 55,000 subunit \\
Histidine & $27.1 \pm 0.2$ & 27 \\
Arginine & $13.9 \pm 0.4$ & 14 \\
Aspartic Acid & $25.0 \pm 0.3$ & 25 \\
Threonine & $52.1 \pm 0.3$ & 52 \\
Serine & $25.1^{\mathrm{a}}$ & 25 \\
Glutamic Acid & $26.1^{\mathrm{a}}$ & 26 \\
Proline & $61.9 \pm 0.4$ & 62 \\
Alanine & $13.2 \pm 0.2$ & 13 \\
Glycine & $36.1 \pm 0.3$ & 36 \\
Valine & $46.1 \pm 0.4$ & 46 \\
Methionine & $36.0 \pm 0.4$ & 36 \\
Isoleucine & $9.0^{\mathrm{a}}$ & 9 \\
Leucine & $21.4 \pm 1.2$ & 21 \\
Tyrosine & $41.2 \pm 0.3$ & 41 \\
Phenylalanine & $11.0 \pm 0.3$ & 11 \\
\hline
\end{tabular}

${ }^{a}$ Extrapolated value of zero time hydrolysis.

Determination of of isoceletric point of mouse glucose-6-phosphate dehydrogenase

The isoelectric point of glucose-6-phosphate dehydrogenase was determined using an LKB preparative Isoelectric Focusing Apparatus in a column size of $110 \mathrm{ml}$. From this study the isoelectric point of glucose-6-phosphate dehydrogenase was found to be $4.8 \pm 0.1$.

\section{Biochemical Characterization}

$p H$ dependence of activity

The enzymatic activity of glucose-6-phosphate dehydrogenase was found to increase about 
threefoldfrom $\mathrm{pH} 5.8$ to 7.0 after which the activity stayed essentially constant until $\mathrm{pH} \mathrm{9.0.} \mathrm{The}$ presence of $\mathrm{MgCl}_{2}$ in the assay mixture had no effect on the enzymatic activity.

Coenzyme and substrate specificity

Several coenzyme and substrate analogs were employed for enzyme assays. Under the described assay conditions, TNADP ${ }^{+},(\mathrm{AcPy}) \mathrm{ADP}^{+}$ and $\mathrm{NHDP}^{+}$exhibit $58 \%, 14 \%$ and $60 \%$ respectively of the enzymatic activity as compared to NADP ${ }^{+}$. Less than $1 \%$ of activity was observed with $\mathrm{NAD}^{+}$as coenzyme. No tissue variation of coenzyme specificity was observed. Galactose-6-phosphate and 2-deoxy-glucose-6phosphate exhibit only $5 \%$ and $3 \%$ respectively of the activity of glucose-6-phosphate.

\section{Inactivation studies.}

In the presence of $2 \mathrm{M}$ urea in $0.1 \mathrm{M}$ tris- $\mathrm{HCl}$ buffer at pH 8.0, glucose-6-phosphate dehydrogenase was inactivated with time. About $40 \%$ of the original activity remained after $15 \mathrm{mi}$ nutes of incubation. In contrast, the enzyme is stable in $10 \mathrm{~mm}$ iodoacetate for at least $30 \mathrm{~min}$. The enzyme was inactivated with time at $47^{\circ}$. More than $50 \%$ of the enzyme activity was lost after $15 \mathrm{~min}$ of incubation in $0.1 \mathrm{M}$ tris-maleate buffer at $\mathrm{pH} 7.0$. However, the enzyme was found to be protected against thermal inactivation by including $0.3 \mathrm{~mm} \mathrm{NADP}{ }^{+}$in the incubation buffer. In contrast, the presence of $1 \mathrm{mM}$ glucose-6-phosphate destabilized the enzyme against thermal denaturation. The results of this study are summarized in Figure 1.

\section{Steady state kinetics}

Glucose-6-phosphate dehydrogenase from mice exhibits normal kinetic patterns and catalyzes the irreversible oxidation of glucose-6phosphate. $\mathrm{K}_{\mathrm{m}}$ 's for glucose-6-phosphate and $\mathrm{NADP}^{+}$were determined to be $50 \mu \mathrm{M}$ and $10 \mu \mathrm{M}$ respectively. NADPH was a competitive inhibitor of $\mathrm{NADP}^{+}$with a $\mathrm{K}_{\mathrm{i}}$ of $18 \mu \mathrm{M} . \mathrm{Mg}^{++}$ ion has no effect on the determined kinetic constants. No tissue variation of these kinetic parameters were found. AMP or ATP showed very little inhibition of this enzyme even at a nucleotide concentration of about $5 \mathrm{~mm}$.

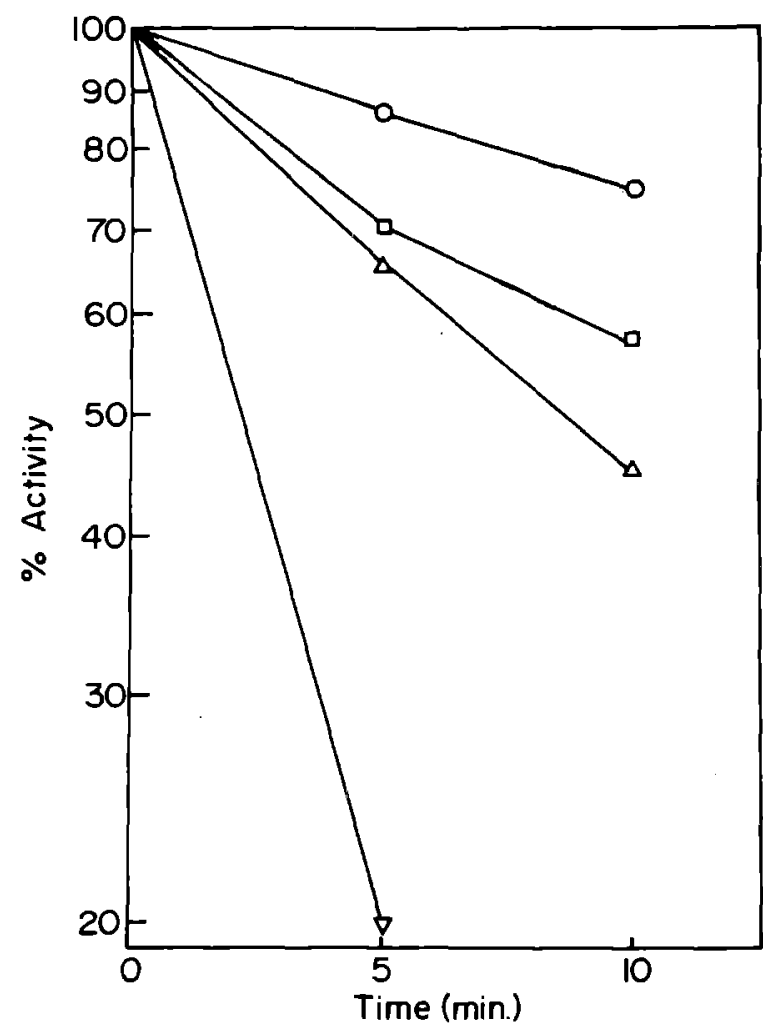

Fig. 1. Stability of glucose-6-phosphate dehydrogenase from DBA/2J mice under various experimental conditions: $-\mathrm{O}$ - denotes the percentage of activity remaining after incubation at $50^{\circ}$ in the presence of $0.3 \mathrm{~mm} \mathrm{NADP}{ }^{+}$in $0.1 \mathrm{M}$ tris-maleate buffer at $\mathrm{pH} 7.0 ;-\triangle-$ is that in the presence of $2 \mathrm{M}$ urea in tris- $\mathrm{HCl}$ buffer at $\mathrm{pH} 8.0$ and $25^{\circ} ;-\square-$ represents the remaining activity at $47^{\circ}$ in $0.1 \mathrm{M}$ trismaleate at $\mathrm{pH} 7.0 ;-\nabla-$ represents that in the presence of $1 \mathrm{~mm}$ glucose-6-phosphate at $47^{\circ}$ in the same buffer.

\section{Immunological studies}

The rabbit antiserum against glucose-6phosphate dehydrogenase from DBA/2J mice exhibits identical precipitin patterns (by double immuno diffusion) with red blood cell, liver, kidney and testis homogenates. In all cases two precipitin lines were evident, a major very heavy line and a faint minor precipitin line. When the red blood cell hemolysate was made with $0.5 \mathrm{mM} \mathrm{NADP}^{+}$instead of distilled water, the intensity of the minor precipitin line was significantly decreased. The specificity of the antiserum was further tested by immunoelectrophoresis with mouse red blood cell hemolysate. Two plates were run identically; the first was developed with the antisera and the second was stained for the enzyme activity. A single precipitin arc was observed on the first plate and its position was identical to that of the spot 


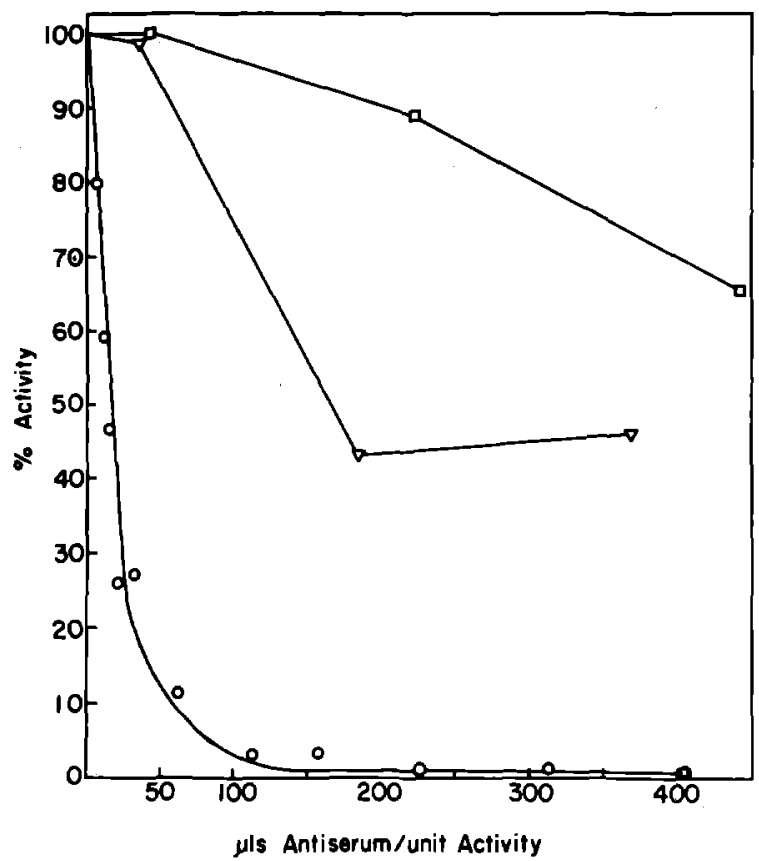

Fig. 2. Inhibition of the enzyme activity of glucose-6phosphate dehydrogenase from DBA/2J mice $(O)$, guinea pig $(\square)$ and human $(\nabla)$ by rabbit antisera to mouse glucose6-phosphate dehydrogenase.

that appeared on the second plate which was stained with the activity of glucose-6-phosphate dehydrogenase.

The ability of the antiserum to inactivate glucose-6-phosphate dehydrogenase was demonstrated with the red blood cell hemolysates from DBA/2J mice, guinea pig and human respectively. Normal rabbit serum did not change significantly the enzyme activity as compared to the saline control. As shown in Figure 2 , human and guinea pig enzymes were partially inactivated with more inhibition of the human enzyme than the guinea pig enzyme.

\section{Discussion}

In this communication, a simple two-step procedure for the preparation of glucose-6-phosphate dehydrogenase from the mouse is described. Although 8-(6-aminohexyl)-amino-AMP is a weak inhibitor $\left(\mathrm{K}_{\mathrm{i}} \geqslant 5 \mathrm{~mm}\right), 8$-(6-aminohexyl)amino-AMP-Sepharose column does exhibit good affinity for the mouse enzyme. Glucose-6phosphate dehydrogenase was eluted from the affinity column by including $\mathrm{NADP}^{+}$in the elution buffer. Further purification of this enzyme through an 8-(6-aminohexyl)-amino-2', $5^{\prime}$ -
ADP-Sepharose column resulted in the homogeneous preparation of this enzyme. The same procedure could also be applied to the purification of glucose-6-phosphate dehydrogenase from many other species such as Drosophila and human (C. -Y. LEE, unpublished data). Since 8-(6-aminohexyl)-amino-AMP-Sepharose column is commonly employed for the purification of $\mathrm{NAD}^{+}$-dependent enzymes, the exact mode of the binding of glucose-6-phosphate dehydrogenase, an $\mathrm{NADP}^{+}$-specific enzyme, remains to be investigated. The results of the inhibition studies seem to indicate that the weak inhibition of glucose-6-phosphate dehydrogenase by this ligand could be due to the competitive binding of this ligand to either $\mathrm{NADP}^{+}$or glucose-6-phosphate binding site of the enzyme. In view of the high $K_{i}$ observed for this ligand, other types of interactions such as hydrophobic or electrostatic interactions between the enzyme and the affinity column can not be ruled out.

8-(6-Aminohexyl)-amino-2', 5'-ADPSepharose has been shown to be an excellent affinity gel for many $\mathrm{NADP}^{+}$-dependent enzymes $^{6}$. In the present study, this affinity column was employed as a second-step for the enzyme purification. Ín view of its high affinity for the mouse glucose-6-phosphate dehydrogenase, the enzyme could only be eluted biospecifically with $\mathrm{NADP}^{+}$in the presence of $50 \mathrm{~mm}$ phosphate buffer at $\mathrm{pH} 6.5$ rather than $10 \mathrm{~mm}$ buffer.

Two enzymes which are coded by two different genes are responsible for the oxidation of glucose-6-phosphate in the mouse and other mammalian species. Glucose-6-phosphate dehydrogenase which has been studied in this work is highly specific for glucose-6-phosphate and NADP ${ }^{+}$. This is in contrast to hexose-6phosphate dehydrogenase, a microsomal enzyme, which has been shown to exhibit broad coenzyme and substrate specificity ${ }^{4,14,15}$.

The amino acid compositions of the purified glucose-6-phosphate dehydrogenase from mice revealed a great similarity between the human and the mouse enzyme. The number of amino acid residues for lysine, arginine, aspartic acid, and isoleucine in mouse enzyme were found to be identical to those of the human enzyme ${ }^{16}$. This result suggests a high degree of conservation in terms of its primary structure during the evolutionary process ${ }^{14}$. 
From the determination of molecular weight by gel filtration and SDS acrylamide gel electrophoresis, it was clearly shown that glucose-6phosphate dehydrogenase from mice is a tetramer of 220,000 daltons. However our immunological study seemed to indicate that there is a dimer-tetramer equilibrium in the absence of $\mathrm{NADP}^{+}$which resulted in the appearance of two precipitin lines in double immunodiffusion. This is similar to enzymes from other sources, where they coexist in both dimeric and tetrameric forms ${ }^{4}$.

The specificity of rabbit antisera to mouse glucose-6-phosphate dehydrogenase was examined by several immunological techniques. Double immunodiffusion of the antiserum against mouse red blood cell hemolsate produced a major and a minor precipitin line while no precipitin line was evident with human or guinea pig red cell hemolysate. The enzyme inactivation studies showed that the antiserum completely inactivates mouse glucose-6phosphate dehydrogenase while the human and guinea pig enzyme are only partially inactivated. From these two studies, one can suggest that antiserum against mouse enzyme does not form precipitable antigen-antibody complexes with the human or guinea pig enzyme.

Mouse glucose-6-phosphate dehydrogenase exhibits similar kinetic mechanism as compared to that from other species. NADPH is a competitive inhibitor to $\mathrm{NADP}^{+}$in the enzyme catalyzed reaction. Since the intracellular NADPH/NADP ${ }^{+}$ratio is high, the apparent intracellular activity of glucose-6-phosphate dehydrogenase is only less than $5 \%$ of the $V_{\max }$, because of the inhibition by intracellular $\mathrm{NADPH}^{18}$. Due to the weak inhibition by ATP $\left(K_{i} \geqslant 5 \mathrm{~mm}\right)$, the intracellular ATP may not have any significant effect on glucose-6-phosphate dehydrogenase activity in vivo. This is in contrast to the human and pig liver enzyme where the inhibition by ATP is apparent ${ }^{4,19}$.

The inactivation studies of mouse glucose-6phosphate dehydrogenase revealed that this enzyme is significantly protected by the coenzyme but not the substrate against thermal denaturation. Inactivation study with iodoacetate also indicated that there are no essential thiol groups near the active sites of this enzyme.

In summary, the molecular and biochemical properties of mouse glucose-6-phosphate de- hydrogenase were characterized in detail. The obtained information should prove to be valuable for the biochemical screening of the mutant enzymes from the mutagen-treated mouse populations.

\section{Acknowledgement}

The authors wish to thank Dr. RoBERT ERICKson from Department of Human Genetics at University of Michigan for helpful discussions regarding this research work and for providing us with the support for immunological studies. (supported by grant GM 15419, N.I.H.)

\section{References}

1. Kirkman, H. N. and Henderson, E. N., 1963. Amer. J. Hum. Genet., 15, 241.

2. Mathai, C. K., Ohno, S. and Beutler, E., 1966. Nature, 210, 115-116.

3. Richardson, B. J., Czuppon, A. B. and Sharam, G. B., 1971. Nature, 230, 154-155.

4. Yoshida, A., 1975. In "Isozymes", vol. IV, ed. Markert, C., Acad. Press, New York, pp. 853-866.

5. Kaplan, N. O., Everse, J., Dixon, J. E., Stolzenbach, F., Lee, C. -Y., Lee, C. -L., Taylor, S. S. and Mosbach, K., 1974. Proc. Nat. Acad. Sci., 71, 3450-3454

6. Lee, C. -Y. and Kaplan, N. O., 1975. Arch. Biochem. Biophys. 168, 665-676.

7. Deflora, A., Ginliano, F. and Morelli, A., 1973. Ital. J. Biochem., 22, 258-270.

8. DeFlora, A., Morelli, A., Benatti, U. and Ginliano, F., 1975. Arch. Biochem. Biophys., 169, 362-363.

9. Yoshida, A., 1975. J. Chromatog., 114, 321-327.

10. Lee, C. -Y., Lappi, D. A., Wermuth, B., Everse, J. and Kaplan, N. O., 1974 Arch. Biochem. Biophys., 163, 561-569.

11. Bohlen, P., Stein, S., Dairman, W. and Udenfriend, S., 1973. Arch. Biochem. Biophys. 155, 213-220.

12. Andrews, P., 1964. Biochem. J. 91, 222-233.

13. Moore, S., Sparkman, D. H. and Stein, H. A., 1958. Anal. Chem. 30, 1185.

14. Yoshida, A., 1966. J. Biol. Chem., 241, 4966-4976.

15. Beutler, E. and Morrison, M., 1967. J. Biol. Chem., 242, 5289-5293.

16. Yoshida, A., 1973. Arch. Biochem. Biophys., 159, 82-88.

17. Yoshida, A., and Hoagland, V. D., 1970 Biochem. Biophys. Res. Commun., 40, 1167-1172.

18 Thompson, R. E. Spivey, H. O., and Katz, A. J., 1976. Biochem. J. 15, 862-867.

19. Yoshida, A., 1973. Science, 179, 532-537.

20. Spielman, H., Erickson, R. P. and Epstein, C. J., 1974. Anal Biochem, 59, 462-467. 